\title{
Performance, emission and combustion characteristics of an indirect injection (IDI) multi-cylinder compression ignition (CI) engine operating on neat jatropha and karanj oils preheated by jacket water
}

\author{
A. K. Hossain and P. A. Davies* \\ Sustainable Environment Research Group, School of Engineering and Applied Science, Aston \\ University, Birmingham B4 7ET, UK.
}

\begin{abstract}
Renewable non-edible plant oils such as jatropha and karanj have potential to substitute fossil diesel fuels in CI engines. A multi-cylinder water cooled IDI type CI engine has been tested with jatropha and karanj oils and comparisons made against fossil diesel. The physical and chemical properties of the three fuels were measured to investigate the suitability of jatropha and karanj oils as fuels for CI engines. The engine cooling water circuit and fuel supply systems were modified such that hot jacket water preheated the neat plant oil prior to injection. Between jatropha and karanj there was little difference in the performance, emission and combustion results. Compared to fossil diesel, the brake specific fuel consumption on volume basis was around 3\% higher for the plant oils and the brake thermal efficiency was almost similar. Jatropha and karanj operation resulted in higher $\mathrm{CO}_{2}$ and $\mathrm{NO}_{\mathrm{x}}$ emissions by $7 \%$ and $8 \%$ respectively, as compared to diesel. The cylinder gas pressure diagram showed stable engine operation with both plant oils. At full load, the plant oils gave around $3 \%$ higher peak cylinder pressure than fossil diesel. With the plant oils, cumulative heat release was smaller at low load and almost similar at full load, compared to diesel. At full load, the plant oils exhibited 5\% shorter combustion duration. The study concludes that the IDI type CI engine can be efficiently operated with neat jatropha (or karanj) oil preheated by jacket water, after small modifications of the engine cooling and fuel supply circuits.
\end{abstract}

Keywords: Non-edible plant oil, CI engine, Performance, Combustion, Emissions, Biofuel

*corresponding author. Tel.: +44(0)1212043724; fax: +44(0)1212043683.

E-mail address: p.a.davies@aston.ac.uk (P.A. Davies).

\section{Introduction}

The total estimated world greenhouse gas (GHG) emissions in the year 2005 amounted to 44 billion tonnes of $\mathrm{CO}_{2}$ equivalent, of which $66.5 \%$ were associated with energy services. Of the total emissions, the share from transportation, electricity and heat was $39.2 \%$ - corresponding to $59 \%$ of the emissions related to energy services [1]. Internal combustion engines, gas turbines and steam turbines are widely used in the provision of these services. Use of internal combustion engines, and especially CI engines, is rapidly growing for small-to-medium scale decentralised power, irrigation, combined heat and power, and tri-generation applications due to a number of advantages e.g. robustness, high efficiency, fuel flexibility. Therefore a substantial reduction in GHG emissions is possible by replacing fossil diesel in CI engines with biomass derived renewable fuels. Different types of liquid biofuels have been discussed in the literature [2-5]. One of these is non-edible or edible plant oil, either neat or blended with fossil diesel [6-12]. Plant oils can also be transesterified to produce biodiesel [13-15]. However, neat (unprocessed) plant oils offer considerable life cycle energy and GHG emission savings compared to both biodiesel and fossil diesel [16,17]. Use of neat oils also offers economic advantages due to the fewer requirements for machinery, chemicals and processes.

Plant oil, when blended with fossil diesel or transesterified into biodiesel, does not generally require any engine modification [18,19]. Modification is recommended, however, if the plant oil is used 
directly in neat form, mainly due to higher viscosity of the plant oils compared to fossil diesel which leads to incomplete combustion and coke formation inside the cylinder and in fuel supply systems including the injectors [16,20,21]. For example, in one study, Bari [21] reported that, after 500 hours of running with crude palm oil, maximum power decreased by $20 \%$ and minimum brake specific fuel consumption increased by $26 \%$. Heavy carbon deposits in the combustion chamber and wear in the injector pump plunger and delivery valve were also observed [21]. Plant oils are usually preheated to reduce the viscosity before injection for better engine performance and reduced emissions. Typically engine exhaust gas [22-24] or electricity $[7,8,10,25,26]$ has been used for preheating. Use of engine exhaust gas is better as it utilises waste heat and therefore involves no additional running costs; however, it requires close monitoring and control of the exhaust gas flow and temperature of the preheated oil. Overheating due to either malfunction or sudden overloading of the engine could cause the oil to flash. Preheating by exhaust gas therefore requires automation in order to meet health and safety requirements, which can be expensive. An alternative is to use the engine jacket water for preheating. In one recent study, for example, Basinger et al. [20] designed and installed a V-shaped plug type oil preheater by modifying the Change Over Valve (COV) of the Lister engine, which collected heat from the cooling water jacket. The heat transfer modelling and identification of the channel geometry of the preheater enabled the authors to maintain the oil temperature before the injector at about $90^{\circ} \mathrm{C}$ across all engine loads [20].

To avoid direct competition with food crops, non-edible plant oils are an attractive substitute for fossil diesel fuel. Of the non-edible plant oils, jatropha (Jatropha curcas) and karanj (Pongamia pinnata) have received considerable attention [27-31] mainly due to their availability and ease of cultivation. The jatropha tree is notable for its tolerance of poor soils and dry climates. Karanj is a forest tree that is especially interesting as a nitrogen fixing species. Their oils have usually been evaluated separately in different engines and under different test conditions [22-24, 28, 32-35]. Moreover, most studies were conducted in only single cylinder engines of mainly direct injection (DI) type with compression ratios in the range of 16.5-18.5 [22-24, 28, 32-35]. Only a few studies investigated engine combustion characteristics [23, 32]. Chauhan et al. [22] tested preheated and unheated jatropha oil in a $5.9 \mathrm{~kW}$ single cylinder DI engine; jatropha oil was preheated to $100^{\circ} \mathrm{C}$ and they reported $3 \%$ decrease in thermal efficiency when compared to fossil diesel operation. These authors reported that NOx emission was lower than fossil diesel in the case of unheated jatropha operation, but increased by $45 \%$ when preheated jatropha was used [22]. Preheated neat karanj oil gave around $40 \%$ increase in Brake Specific Fuel Consumption (BSFC) and 25\% decrease in brake thermal efficiencies as compared to fossil diesel operation [23]. Khatri et al. [24] investigated the effect of injection timing on engine performance when operated on preheated karanj oil-diesel blends using a single cylinder $3.7 \mathrm{~kW}$ Kirloskar DI engine with compression ratio of 16.5 and injection timing of $23^{\circ}$ BTDC. The thermal efficiency of the 40:60 karanj-diesel blend was found to be similar with fossil diesel operation at optimum injection timing of $19^{\circ}$ BTDC. In another similar study, $23 \%$ higher BSFC, $14 \%$ lower brake thermal efficiency and $15 \%$ higher $\mathrm{CO}_{2}$ emission were reported with preheated neat jatropha oil used instead of fossil diesel in a single cylinder DI engine with compression ratio of 17.5 [35].

As interest in jatropha and karanj is growing, it is important to investigate these oils in CI engines of types not prominent in the current literature. Furthermore, for valid comparison, the oils need to be tested in the same engine and under the same conditions. Given the high viscosity of plant oils, use of an IDI type engine may be advantageous over DI, because mixing of the plant oil with air should be better due to the turbulence created by the partial burning in the secondary combustion chamber (prechamber) of the IDI engine. Consequently, it is expected that, the combustion of high viscous plant oils will be better in IDI type engine, and the coke formation in the combustion chamber will be minimum. Furthermore, $\mathrm{NO}_{\mathrm{X}}$ emission may be lower in the IDI than in the DI engine, due to the lack of air in the secondary combustion chamber and lower temperature in the main combustion chamber [36]. With the aim of verifying these anticipated benefits, an experimental study of the performance, exhaust emissions and combustion parameters of a multi-cylinder IDI type CI engine running on neat plant oils is presented in this study. Jatropha and karanj will be compared against each other and against fossil diesel operation for reference. The engine cooling circuit will be modified so that the hot 
jacket water (which is normally wasted) preheats the plant oil. The physical and chemical characteristics of the fuels will first be measured for use in the performance calculations and evaluation of the results. The study includes combustion analysis by means of cylinder pressure measurements, and a preliminary investigation of the coke formation inside the cylinder, piston and injectors.

\section{Materials and methods}

\subsection{Fuel Characterisation}

Jatropha oil produced in Ghana was obtained from a UK supplier (Matrix Biofuels Ltd.), whereas karanj oil produced in India was obtained from an Indian supplier (A-Mark Procon Ltd.). The oils were cleaned in the laboratory using 10,5 and $1 \mu \mathrm{m}$ sock filters. A Parr 6100 bomb calorimeter was used to measure the higher heating values (HHV). Canon Fenski u-tube viscometers and thermostatic water bath $\left( \pm 0.1^{\circ} \mathrm{C}\right)$ were used to measure the kinematic viscosities at different temperatures according to ISO 3104 having an accuracy of $\pm 0.22 \%$. The $\mathrm{pH}$ values were measured using a HACH HQ40d meter and densities using a standard hydrometer. Flash point was measured using a Setaflash series 3 plus closed cup flash point tester (model 33000-0). A Shatox OPLCM instrument was used to measure the cetane number, pour point temperature and filterability temperatures. Elemental analysis to investigate the carbon, hydrogen, nitrogen, oxygen and sulphur content ( $\% \mathrm{wt}$ ) was performed by an accredited laboratory using a Thermo EA1108 series elemental analyser. The lower heating value (LHV) was calculated from the HHV and hydrogen content.

\subsection{Experimental set-up}

The specifications of the IDI water cooled CI engine selected for the study are given in Table 1 . The experimental set-up, including modifications carried out to the engine fuel supply and cooling water systems, is shown in Fig. 1.

\subsubsection{Fuel supply and preheat}

A dual-fuel supply system was designed so that the engine can be started and warmed up with fossil diesel before switching to plant oil after about 10 minutes (Fig. 1). At the end of each test run reversion to diesel operation flushed the remaining plant oil from the fuel supply and engine injection system. This avoided clogging of the fuel filters and injector holes due to thickening of the oil once the system cools. The fuel supply lift pump supplied with the engine was disconnected, and the spill from the injector was connected to the main fuel supply line using a T-connector. Additional filters were connected into the fuel supply system. The fuel supply tanks were placed at $3 \mathrm{~m}$ height for reliable fuel flow and to overcome the pressure losses in the additional fuel filters and heat exchanger (HX). Note that Bari et al. [37] have already reported the advantages as regards power output of connecting additional fuel filters and raising the fuel supply tank in plant-oil fuelled engine operation. Two $12 \mathrm{~V}$ DC fuel transfer pumps were installed to transfer the fuels from the ground tank to the overhead tanks (not shown). Stainless steel piping and valves were used to avoid any corrosion or erosion.

At full load, engine jacket water temperature is around $100^{\circ} \mathrm{C}$ with a flow of $33 \mathrm{l} / \mathrm{min}$ (Table 1); this means that a considerable amount of the heat energy is available in the hot jacket water. To preheat the plant oil with this water, a plate type HX was connected to the engine jacket water cooling system via two manually operated valves that were opened when using plant oils but kept closed for diesel. Another manually operated valve controlled the flow of the hot jacket water to the plate HX and hence the temperature of the preheated plant oils (Fig. 1). 
In a standard engine, hot jacket water is cooled by a radiator and fan and then returned to the cooling circuit. To facilitate testing within a standard test cell, however, the radiator was by-passed by a header tank type HX (Bowman UK) supplied with tap water. Although the radiator water pipes were disconnected from the engine, the radiator itself and the fan were not disconnected to enable comparisons of the engine performance with the rated figures provided by the manufacturer. Moreover the radiator fan was needed to cool the engine accessories.

\subsubsection{Instrumentation}

An eddy current dynamometer (Froude Hofmann AG80HS) was used to measure and adjust the engine load and speed (Fig. 1). The torque and speed accuracies of the dynamometer were $\pm 0.4 \mathrm{Nm}$ and $\pm 1 \mathrm{rpm}$ respectively. A five-gas emission analyser (Bosch BEA 850) and smoke opacity meter (Bosch RTM 430) were used to analyse the exhaust gas components and to measure the smoke intensity respectively. A graduated cylinder and stop watch were used to measure the fuel consumption rate (Fig. 1). K-type thermocouples were used to measure the temperatures of the exhaust gas, fuel inlet, lub oil and engine jacket water. Fuel temperature was measured immediately after the plate HX and after the fuel injection pumps ie. just before the injector, thus approximating as closely as possible the temperature of the injected fuel (Fig. 2). A LabVIEW data acquisition system was used to $\log$ the temperatures at the various locations. The dynamometer was calibrated and the calibration curve (not shown) was used to obtain the brake torque applied at the engine shaft. The engine was operated at different loads at a constant speed of $1500 \mathrm{rpm}$. Brake thermal efficiency was calculated based on LHV.

A pressure sensor (Kistler 6125C11) and charge amplifier (Kistler 5064B11) were used to measure pressure in the cylinder nearest the radiator end of the engine. A suitable location in the main combustion chamber was identified and a mounting sleeve with locking mechanism was designed and fabricated for this installation. Machining of the cylinder head through the water jacket was performed accordingly (Fig. 2). The sensor was not installed flush to the combustion chamber surface; rather it was recessed by $2 \mathrm{~mm}$ to avoid damage to the diaphragm and to aid maintenance. Another pressure sensor (Kistler 4065A500A0) and amplifier (Kistler 4618A0) were used to measure the fuel line injection pressure (Fig. 2). This sensor was installed on the fuel delivery line of the same cylinder. An optical encoder (Kistler 2614A) was installed for detection of the crank angle position. The amplifiers and the encoder electronics were connected to the 'KiBox' (Kistler, model 2893AK8) for data logging, which was connected to a PC through the ethernet port (Fig. 1). KiBoxCockpit software was used to measure and analyse the various engine combustion parameters.

\section{Results and discussion}

\subsection{Fuel properties}

With regard to LHV, density and cetane number, Table 2 shows only very small differences between karanj and jatropha and minor differences of both plant oils compared to fossil diesel. The LHVs of the plant oils were lower by about $11 \%$ and their densities higher by about $12 \%$. Their cetane numbers were almost $10 \%$ lower than for fossil diesel. In contrast, their viscosities and flash point temperatures were considerably higher than those of diesel. Viscosity of the plant oils is temperature dependent and can be reduced by $80-90 \%$ through preheating to $90^{\circ} \mathrm{C}$ (Fig. 3). Note that high flash point is advantageous as regards safety in storage, handling and preheating.

The carbon content in the fossil diesel was 7-8\% higher than in the plant oils. Nitrogen content in jatropha oil was much higher than in karanj oil and in fossil diesel (Table 2). Hydrogen content was comparable to fossil diesel but oxygen content was 6 to 7 times higher in the plant oils. For all three fuels sulphur was at trace levels. The properties of any plant oil depend on the plant variety and 
conditions of cultivation; however, the properties of the oils measured in our study are in line with those found in the literature [16].

\subsection{Engine performance and exhaust emissions}

Preheating raised the temperature of the oils to $58-75^{\circ} \mathrm{C}$, the higher temperatures being achieved at higher brake power outputs due to increasing jacket water temperature (Fig. 4). Although the HX was installed close to injection pump, the temperature of the fuel dropped by $12-15^{\circ} \mathrm{C}$ by the time it reached the injectors (Fig. 4). The level of preheating achieved by using the jacket water reduced the viscosity of the oil considerably by $60-70 \%$ (Fig. 3).

At full load, BSFC was $16 \%$ and $3 \%$ higher on weight and volume bases respectively, when the engine was fuelled with preheated neat jatropha (or karanj) oil, as compared to unheated fossil diesel (Fig. 5a, 5b). Because the calorific value of the jatropha or karanj oil is lower than that of fossil diesel, more fuel is needed for the same engine output. In addition, although the plant oils were preheated to $60-75^{\circ} \mathrm{C}$, they remained 10 times more viscous than diesel leading to less efficient mixing of fuel and air. These factors explain the somewhat higher fuel consumptions. Comparison on a volume rather than weight basis showed smaller differences in BSFC due to the higher densities of the plant oils (Table 2). Between jatropha and karanj, BSFC results were very close on both weight and volume bases (Fig. 5a, 5b). Brake thermal efficiencies from both plant oils were close to those from diesel at high load, but $10 \%$ lower than from diesel at low load condition (Fig. 5c).

At low loads, $\mathrm{CO}$ and $\mathrm{CO}_{2}$ emissions were almost the same for all fuels (Fig. 6a, 6b). The amount of intake air (i.e. oxygen content) was constant throughout the engine test - so, at higher loads the fuel to air ratio decreased (lower lambda values) and hence $\mathrm{CO}$ emission increased sharply due to the lower oxygen content in the mixture. In the case of jatropha and karanj oil operation and at higher load conditions, $\mathrm{CO}$ and $\mathrm{CO}_{2}$ emissions were higher than with fossil diesel as higher amounts of the plant oils were burned for the same engine output (Fig. 6a, 6b). In addition, it is probable that the higher oxygen content in the plant oils helped to combust the jatropha (or karanj) oil and caused higher $\mathrm{CO}_{2}$ emission than with fossil diesel. At full load condition, $\mathrm{CO}_{2}$ emission was $7 \%$ higher for plant oil operation (Fig. 6b). It was also observed that at higher load condition, $\mathrm{CO}$ emission was slightly higher with jatropha than karanj. This may be explained by the lower oxygen content in the jatropha oil.

Higher combustion temperatures in $\mathrm{CI}$ engines generally give higher $\mathrm{NO}_{\mathrm{x}}$ emission. For jatropha and karanj operation, $\mathrm{NO}_{\mathrm{x}}$ emissions were $8 \%$ higher than fossil diesel in these tests (Fig. 6c). This is consistent with the higher peak cylinder pressures observed with the plant oils (section 3.3), as higher pressures are normally associated with higher combustion temperatures. Oxygen emissions were almost similar under low load conditions for all fuels; but at high loads $\mathrm{O}_{2}$ emissions were lower for jatropha (or karanj) oil operation (Fig. 6d). Higher level of fuel-borne oxygen in the jatropha (or karanj) oil probably caused this difference.

Exhaust temperature is important for co-generation applications (CHP and tri-generation). Little difference was observed in exhaust temperatures among the three fuels tested (Fig. 7a). At high load condition, the smoke opacity values were slightly higher than fossil diesel when the engine was operated either on jatropha or karanj oil (Fig. 7b). Lambda values were found to be mostly similar for all fuels (Fig. 7c). However, at higher loads, lower lambda values were observed for plant oil operation corresponding to the higher BSFC.

At low load, an additional means to preheat the oil is desirable, as the jacket water temperature is low. An off-the-shelf glow plug type electrical heater could be used for this purpose. This type of heater is powered by the engine alternator and can be switched on during low load operation. Overall, the performance and exhaust emission results obtained in the current study compare favourably to those typically reported in the literature from studies on DI engines [23, 32-35]. Use of an IDI type engine, 
with additional fuel filters and raised fuel tank, caused this better engine performance. Previous studies were mostly conducted in single cylinder DI engines with compression ratios in the range of 16.5-18.5, whereas the compression ratio of the engine used in this study was 22. Although the engine was not tested at other compression ratios, it is believed that this high compression ratio could be another reason for better engine performance and emission.

\subsection{Combustion characteristics}

Stable engine operation was obtained regardless of fuel and load, as evident from the smooth pressure-crank angle diagram (Fig. 8). No significant differences in peak cylinder pressure were noted between jatropha and karanj oils over a range of loads. Compared to fossil diesel, however, peak cylinder pressures were about 3\% higher (Fig. 8). The cylinder pressure profiles before the peak pressure point were almost similar for all three fuels, and only minor variations were observed after the peak cylinder pressure point. For all fuels and load conditions, the peak cylinder pressure occurred between $10^{\circ}$ and $12.5^{\circ}$ crank angle (CA) after top dead centre (ATDC) position. In general, jatropha and karanj oil operation resulted in peak cylinder pressure occurring close to the top dead centre position, earlier than with diesel (Fig. 8).

At low loads, integral heat release from fossil diesel combustion was higher (Fig. 9). This can be explained by the lower preheating temperature and higher viscosities of the plant oils at lower loads (Fig. 3, Fig. 4) leading to incomplete combustion. At higher loads, the heat release behaviour was similar to fossil diesel (Fig. 9). For any specific load condition, peak integral heat release values were almost similar between jatropha and karanj. In general, the fuel line injection peak pressure values were higher in the case of the plant oil operation, due to the higher viscosity values of the plant oil even after preheating (Fig. 10); at full load it was almost 9\% higher than for fossil diesel.

Total combustion duration is defined as the duration of the crank angle between $5 \%$ and $90 \%$ combustion. Ignition delay is another important combustion parameter, which is related to the ignition quality (ie. cetane number) of the fuel. Engine parameters affecting the ignition delay period are: compression ratio, engine speed, cylinder gas pressure, temperature of the air intake, and quality of fuel spray [34]. In the case of plant oil operation, the start of combustion was delayed compared to fossil diesel operation which is consistent with the lower cetane number (Table 2). Total combustion duration increased with engine load for all fuels. The duration was shorter for the plant oils than for diesel (Fig. 11a, 11b). At full load, combustion duration of the jatropha (or karanj) operation was almost 5\% lower than for fossil diesel; no significant differences were observed between jatropha and karanj in this respect.

It was observed that in the case of plant oils, the maximum heat release rates were advanced by about 1 to $2.5^{\circ} \mathrm{CA}$ (figure not shown) relative to fossil diesel. The ignition delay was longer, but the combustion duration was shorter than fossil diesel (Fig. 11). Quick burning in a short period of crank angle duration (i.e. in smaller cylinder volume) caused higher peak cylinder pressures in the case of plant oils. Higher peak cylinder pressures in the case of plant oils have also been reported in the literature $[20,21,26,37]$.

In case of plant oils, the start of combustion was delayed; but once combustion started, the oils burnt quickly resulting in shorter combustion duration than fossil diesel. It is likely that the presence of fuelborne oxygen in the plant oils helped complete combustion, and together with the high ignition delay, this caused shorter combustion duration. Furthermore, it was observed that the peak cylinder pressures and maximum heat release rates were advanced in case of jatropha (or karanj) oil relative to fossil diesel, due to the shorter combustion duration. The higher ignition delay period and shorter combustion duration in the case of plant oils (or blends) resulted in higher peak cylinder pressures than with fossil diesel [38]. The combustion duration or ignition of fuel is a complex system and may depends on many variables, for example: engine type (IDI/DI) and speed, compression ratio, geometry of combustion chamber, injection parameters (IOP, injection timing), injector geometry, 
temperature of air intake and fuel properties. Generally, plant oils or biofuels have lower cetane number than fossil diesel; therefore, longer ignition delays were observed [38-39]. In contrast to this, shorter ignition delay period has also been reported in the literature [23, 26, 37]. Some studies found that fuels with high cetane number have shorter ignition delay and longer combustion duration [4041]. However, both longer [23, 26] and shorter [42-43] combustion duration were reported for plant oils and other biofuels. This is an area where further research work is recommended.

\subsection{Engine durability: coke formation}

Coke deposition inside the engine cylinder and in the fuel supply systems, piston ring sticking, leakage of the plant oils into the crank case, clogging of fuel filters and injectors, engine wear and other engine durability problems were reported in the literature when neat plant oils were used in standard CI engines [16,21,37,44-46]. Although a complete endurance study was not performed during this study, a visual observation of the piston, cylinder, fuel supply system, and injector conditions was carried out after 50 hours of engine operation with preheated non-edible plant oils. A very small amount of coke formation occurred on to the piston surfaces and cylinder heads (Fig. 12). Injectors were inspected and no corrosion or erosion of the injector was observed. The fuel filters were not clogged. Neither engine knocking nor any instability in the engine operation was noticed. Adoption of a preventive maintenance schedule and some changes in the routine maintenance strategy should be conducive to longer term engine operation when the engine is fuelled with these oils.

\section{Conclusions}

A three-cylinder indirect-injection compression ignition engine, with nominal output $9.9 \mathrm{~kW}$ and compression ratio 22 , has been tested with non-edible plant oils from jatropha and karanj trees. Performance, emissions and combustion characteristics were compared against fossil diesel operation. The engine was modified with a heat exchanger such that the plant oils were preheated by the engine jacket water to temperatures of $46-60^{\circ} \mathrm{C}$ prior to injection. The three fuels were characterised and found to have properties similar to those reported in the literature.

Between the jatropha and karanj oils, there were few differences in the results from the engine tests. Compared to fossil diesel, however, there were a number of small but significant differences when using the plant oils:

i. At full load the BSFC was increased by $3 \%$ on a volume basis and $16 \%$ on a weight basis, while brake thermal efficiency was similar.

ii. $\mathrm{CO}_{2}$ and $\mathrm{NO}_{\mathrm{x}}$ emissions were higher by $7 \%$ and $8 \%$ respectively; $\mathrm{CO}$ emissions were similar to fossil diesel operation at low load but at higher loads the plant oils gave slightly higher $\mathrm{CO}$ emissions; the $\mathrm{O}_{2}$ emissions were either similar to or less than those from fossil diesel.

iii. Peak cylinder pressures were slightly higher $(\sim 3 \%)$.

iv. Peak integral heat release values were smaller at low load, translating into a lower efficiency than with fossil diesel, but at full load they were almost the same.

v. At full load, fuel line injection pressure was around $9 \%$ higher.

vi. Total combustion duration was lower under all load conditions.

The cylinder gas pressure diagrams with jatropha and karanj oils indicated stable engine operation with these alternative fuels. This study concludes that, an IDI type CI engine used in the current study combusted the plant oils more efficiently and produced better engine performance, emission and combustion characteristics, compared to results typically reported in the literature using jatropha (or karanj) oil in DI engines with lower compression ratio. This preliminary study reports that neat nonedible jatropha or karanj oils can be used effectively (without blending with fossil diesel or conversion to biodiesel) in a suitably selected CI engine, provided minor modifications to the standard 
engine are made. However, full endurance tests are required to assess the engine durability issues and are recommended as further work.

\section{$\underline{\text { Acknowledgements }}$}

This work was supported by the Research Councils (UK) and DST (Government of India) under the Science Bridges programme (grant number EP/G039992/1). The authors would like to thank $\mathrm{Mr}$ David Smith for providing technical assistance in various stages of the study, and Mr Asrar Razzaq (project student, Aston University) and Mr Dhrubatara Mitra (SRI, Ranchi, India) for their help during the experiments.

\section{REFERENCES}

[1] World Resource Institute. World GHG Emissions Flow Chart; 2010.

[2] Demirbas A. Competitive liquid biofuels from biomass. Appl Energ 2011; 88: 17-28.

[3] Knothe G. Biodiesel and renewable diesel: A comparison. Prog Energ Comb 2010; 36: 264-73.

[4] Nigam PS, Singh A. Production of liquid biofuels from renewable resources. Prog Energ Comb 2011; 37: 52-68.

[5] Naik SN, Goud VV, Rout PK, Dalai AK. Production of first and second generation biofuels: A comprehensive review. Renew Sust Energ Rev 2010; 14: 578-97.

[6] Shehata MS, Abdel Razek SM. Experimental investigation of diesel engine performance and emission charecteristics using jojoba/diesel blend and sunflower oil. Fuel 2011; 90: 886-97.

[7] Yilmaz N, Morton B. Effects of preheating vegetable oils on performance and emission charecteristics of two diesel engines. Biom Bioenerg 2011; 35: 2028-33.

[8] Geo VE, Nagarajan G, Nagalingam B. Experiments on behaviour of preheated rubber seed oil in a direct injection engine. J Energ Inst 2008; 81(3): 177-80.

[9] Ramadhas AS, Jayaraj S, Muraleedharam C. Charecterisation and effect of using rubber seed oil as fuel in the compression ignition engines. Renew Energ 2005; 30: 795-803.

[10] Kalam MA, Masjuki HH. Emissions and deposit characteristics of a small diesel engine when operated on preheated crude palm oil. SAE Paper 2005-01-3697; 2005.

[11] Machacon HTC, Matsumoto Y, Ohkawara C, Shiga S, Karasawa T, Nakamura H. The effect of coconut oil and diesel fuel blends on diesel engine performance and exhaust emissions. JSAE Rev 2001; 22: 349-55.

[12] Wang YD, Al-Shemmeri T, Eames P, McMullan J, Hewitt N, Huan Y, et al. An experimental investigation of the performance and gaseous exhaust emissions of a diesel engine using blends of a vegetable oil. Appl Therm Eng 2006; 26: 1684-91.

[13] Ozsezen AN, Canakci M, Sayin C. Effects of biodiesel from used frying palm oil on the performance, injection and combustion characteristics of an indirect injection diesel engine. Energ Fuels 2008; 22: 1297-1305.

[14] Banapurmath NR, Tewari PG, Hosmath RS. Performance and emission characteristics of a DI compression ignition engine operated on Honge, Jatropha and sesame oil methyl esters. Renew Energ 2008; 33 (9): 1982-8.

[15] Ramadhas AS, Muraleedharan C, Jayaraj S. Performance and emission evaluation of a diesel engine fuelled with methyl esters of rubber seed oil. Renew Energ 2005; 30 (12): 1789-1800.

[16] Hossain AK, Davies PA. Plant oils as fuels for compression ignition engines: A technical review and life-cycle analysis. Renew Energ 2010; 35: 1-13.

[17] Esteban B, Baquero G, Puig R, Riba JR, Rius A. Is it environmentally advantageous to use vegetable oil directly as biofuel instead of converting it to biodiesel? Biom Bioenerg 2011; 35:1317-28.

[18] No SY. Inedible vegetable oils and their derivatives for alternative diesel fuels in CI engines: A review. Renew Sust Energ Rev 2011; 15(1):131-41.

[19] Ndayishimiye P, Tazerout M. Use of palm oil-based biofuel in the internal combustion engines: Performance and emissions characteristics. Energy 2011; 36: 1790-96.

[20] Basinger M, Reding T, Williams C, Lackner KS, Modi V. Compression ignition engine modifications for straight plant oil fueling in remote contexts: Modification design and short-run testing. Fuel 2010; 89 (10): 2925-38. 
[21] Bari S. Investigation into the deteriorated performance of diesel engine after prolonged use of vegetable oil. Paper No. ICEF2004-955. In: Fall Tech Conf of the ASME Internal Comb Engine Div, 24-27 Oct 2004, Long Beach, California, USA; 2004.

[22] Chauhan BS, Kumar N, Jun YD, Lee KB. Performance and emission study of preheated jatropha oil on medium capacity diesel engine. Energ 2010; 35: 2484-92.

[23] Agarwal AK, Dhar A. Karanja oil utilization in a direct-injection engine by preheating. Part 1: experimental investigations of engine performance, emissions, and combustion characteristics. Proc. IMechE Part D: J. Automobile Engineering 2010; 224: 73-84.

[24] Khatri KK, Sharma D, Soni SL, Kumar S, Tanwar D. Investigation of optimum fuel injection timing of direct injection CI engine operated on preheated karanj-diesel blend. Jordan J Mech Ind Engineering 2010; 4(5): 629-40.

[25] Nwafor OMI. Emission charecteristics of diesel engine running on vegetable oil with elevated fuel inlet temperature. Biom Bioenerg 2004; 27: 507-11.

[26] Bari S, Lim TH, Yu CW. Effects of preheating of crude palm oil (CPO) on injection system, performance and emission of a diesel engine. Renew Energ 2002; 27: 339-51.

[27] Shrinivasa U. A viable substitute for diesel in rural India. Current Sci 2001; 80 (12): 1483-4.

[28] Misra RD, Murthy MS. Jatropa - the future fuel of India. Renew Sust Energ Rev 2011; 15:1350-9.

[29] Scott PT, Pregelj L, Chen N, Hadler JS, Djordjevic MA, Gresshoff PM. Pongamia pinnata: an untapped resource for the biofuels: industry of the future. Bioenerg Res 2008; 1: 2-11.

[30] Gilbert N. The seeds of an economy. Nature 23 June 2011; 474: S18-S19.

[31] Achten WMJ, Verchot L, Franken YJ, Mathijs E, Singh VP, Aerts R et al. Jatropha bio-diesel production and use. Biom Bioenerg 2008; 32: 1063-1084.

[32] Reksowardojo IK, Brodjonegoro TP, Arismunandar W, Sopheak R, Ogawa H. The combustion and exhaust gas emission of a direct injection compression ignition engine using physic nut oil (Jatropha Curcas L.oil). SAE Tech Pap Number; 2007-01-3622.

[33] Forson FK, Oduro EK, Hammond ED. Performance of jatropha oil blends in a diesel engine. Renew Energ 2004; 29: 1135-45.

[34] Mahanta P, Mishra SC, Kushwah YS. An experimental study of Pongamia pinnata L. Oil as a diesel substitute. Proc. IMechE Part A: J. Power Energ 2006; 220: 803-808.

[35] Agarwal D, Agarwal AK. Performance and emissions characteristics of Jatropha oil (preheated and blends) in a direct injection compression ignition engine. Appl Therm Eng 2007; 27: 2314-23.

[36] Pucher E. Exhaust Emission. In: Basshuysen RV, Schafer F, editors. Internal Combustion Engine Handbook, Canada: SAE International; 2004, p.576-78.

[37] Bari S, Yu CW, Lim TH. Filter clogging and power loss issues while running a diesel engine with waste cooking oil. Proc IMechE, Part D: J Autom Engg 2002: 993-1001.

[38] Elango T, Thamilkolundhu S. Combustion and emission characteristics of a diesel engine fuelled with jatropha and diesel oil blends. Thermal Science 2011; 15 (4): 1205-14.

[39] Tamilvendhan D, Ilangovan V. Performance, emission and combustion charecteristics os a methyl ester sunflower oil eucalyptus oil in a single cylinder air cooled direct injection diesel engine. Int $\mathbf{J}$ Engg Science Technol 2011;3(3): 1977 - 85.

[40] Kidoguchi Y, Yang C, Kato R, Miwa K. Efects of fuel cetane number and aromatics on combustion process and emissions of a direct-injection diesel engine. JSAE Review 2000; 21: $469-75$.

[41] Yang C, Kidoguchi Y, Kato R, Miwa K. Effects of fuel properties on combustion and emissions of a direct-injection diesel engine. Journal of MESJ 2000; 34(12):55-62.

[42] Rao GLN, Prasad BD, Sampath S, Rajagopal K, Combustion analysis of diesel engine fueled with jatropha oil methyl ester - diesel blends. Int J Green Energ 2007; 4:645-58.

[43] Gogoi TK, Talukdar S, Baruah DC. Comparative analysis of performance and combustion of koroch seed oil and jatropha methyl ester blends in a diesel engine. Proc World Renewable Energ Congress 2011, 8-13 May 2011, Sweden: 3533-40.

[44] Murayama T, Young-taig OH, Miyamoto N, Chikahisa T, Takagi N, Itow K. Low carbon flower build up, low smoke and efficient diesel operation with vegetable oils by conversion to mono-esters and blending with diesel oil or alcohols. SAE Paper No.: 841161. USA: SAE; 1984.

[45] Adams C, Peters JF, Rand MC, Schroer BJ, Ziemke MC. Investigation of soybean oil as a diesel fuel extender: endurance tests. J Am Oil Chem Soc 1983; 60: 1574-9.

[46] Mazed MA, Summers JD, Batchelder DG. Engine endurance with peanut, soyabean and cottonseed oil fuels. Trans ASAE 1985; 28: 1371- 4. 
Table 1

Specification of the experimental engine

\begin{tabular}{ll}
\hline Manufacturer & Lister Petter (UK) \\
Model/type & LPWS Bio3 water cooled \\
No. of cylinders & 3 \\
Bore/stroke & $86 / 80 \mathrm{~mm}$ \\
Rated speed & $1500 \mathrm{rpm}$ \\
Continuous power at rated speed & $9.9 \mathrm{~kW}$ \\
Overload power at rated speed & $10.9 \mathrm{~kW}$ \\
Type of fuel injection & Indirect injection. Self-vent fuel system with \\
& individual fuel-injection pumps \\
Fuel pump injection timing & $20^{\circ}$ BTDC \\
Aspiration & Natural \\
Cylinder capacity (litre) & 1.395 \\
Compression ratio & $1: 22$ \\
Firing order & $1-2-3$ \\
Minimum full load speed (rpm) & 1500 \\
Maximum permissible exhaust back pressure (mbar) & 75 \\
Continuous power fuel consumption at 1500 rpm & 3.19 litre/hr (fossil diesel) \\
Glow plug & Combustion-chamber glow plugs \\
Exhaust gas flow & 41.4 litres/sec at full loads at $1500 \mathrm{rpm}$ \\
Jacket water flow at full load & 33 litres/min (at 1500 rpm) \\
Maximum engine jacket water temperature & $99-102^{\circ} \mathrm{C}$ \\
\hline
\end{tabular}


Table 2

Measured properties of jatropha, karanj and fossil diesel

\begin{tabular}{llll}
\hline Physical and chemical properties & Jatropha oil & Karanj oil & Fossil diesel \\
\hline Kinematic viscosity $(\mathrm{cSt})$ at $25^{\circ} \mathrm{C}$ & 56.01 & 79.21 & 3.37 \\
Pour point temperature $\left({ }^{\circ} \mathrm{C}\right)$ & -6.05 & -7.65 & -6.17 \\
Cetane number & 44.6 & 45.6 & 50.2 \\
Filterability temperature $\left({ }^{\circ} \mathrm{C}\right)$ & -7.2 & - & -8.03 \\
Flash point temperature $\left({ }^{\circ} \mathrm{C}\right)$ & 245 & 257 & 70 \\
pH value $@ 22^{\circ} \mathrm{C}$ & 6.21 & 5.82 & 6.85 \\
Density $\left(\mathrm{kg} / \mathrm{m}^{3}\right)$ @ $18^{\circ} \mathrm{C}$ & 916 & 934 & 834 \\
Higher heating value $(\mathrm{HHV})(\mathrm{MJ} / \mathrm{kg})$ & 39.87 & 39.10 & 44.67 \\
Lower heating value $(\mathrm{LHV})(\mathrm{MJ} / \mathrm{kg})$ & 37.25 & 36.61 & 41.87 \\
Carbon $(\% \mathrm{wt})$ & 77.88 & 78.10 & 84.73 \\
Hydrogen $(\% \mathrm{wt})$ & 12.38 & 11.74 & 13.20 \\
Nitrogen $(\% \mathrm{wt})$ & 1.19 & $<0.10$ & $<0.10$ \\
Sulphur $(\% \mathrm{wt})$ & $<0.10$ & $<0.10$ & $<0.10$ \\
Oxygen $(\% \mathrm{wt})$ & 8.75 & 10.30 & 1.40 \\
\hline
\end{tabular}




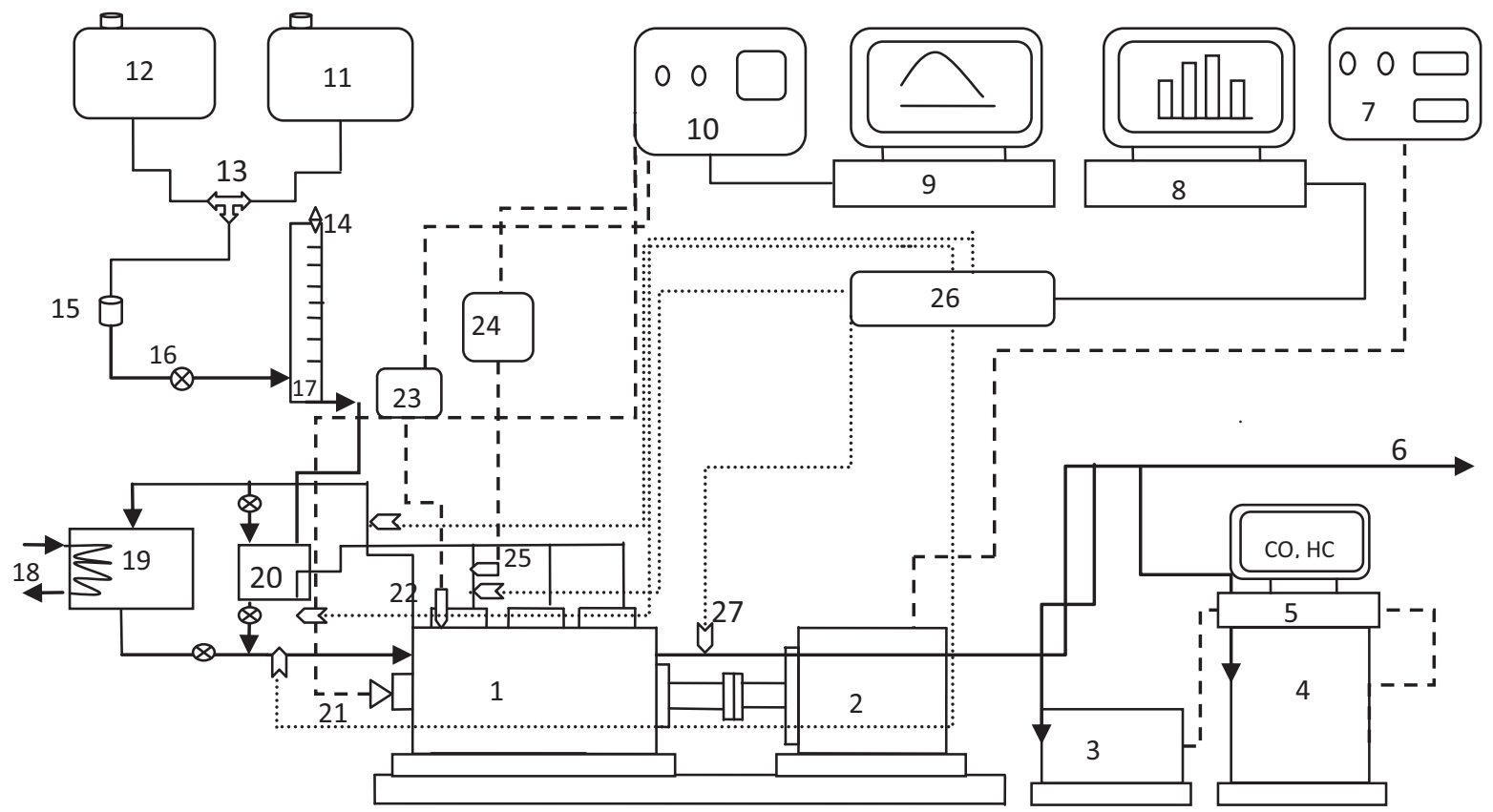

1: Engine; 2: Dynamometer; 3: Smoke meter; 4: Exhaust analyser; 5: Exhaust data acquisition; 6: Exhaust gas discharge; 7: Dynamometer controller; 8: NI data acquisition for temperature; 9, 10: Kistler combustion analyser; 11: Jatropha/Karanj tank; 12: Diesel tank; 13: 3-way valve; 14: Vent screw; 15: Additional fuel filter; 16: Valve; 17: Fuel measurement; 18: Cold water flow to HX; 19: HX to cool jacket water; 20: Plant oil preheater; 21: Crank angle encoder; 22: Cylinder pressure transducer; 23, 24: Amplifier; 25: Injection pressure sensor; 26: NI DAQ; 27: Thermocouple

Fig. 1. Schematic diagram of the engine modifications and experimental rig 


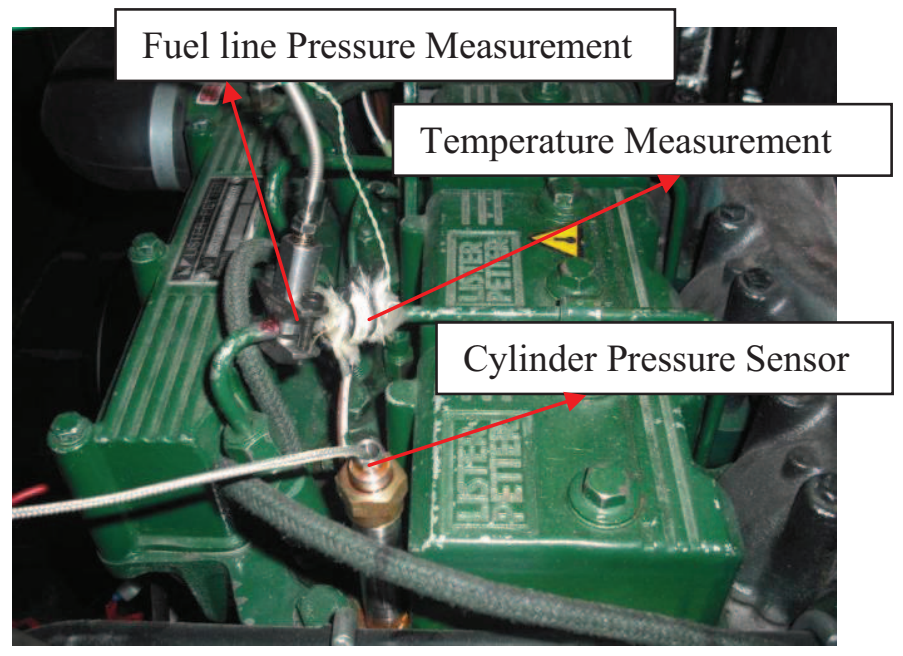

Fig. 2. Measurement of cylinder pressure, and fuel line injection temperature and pressure 


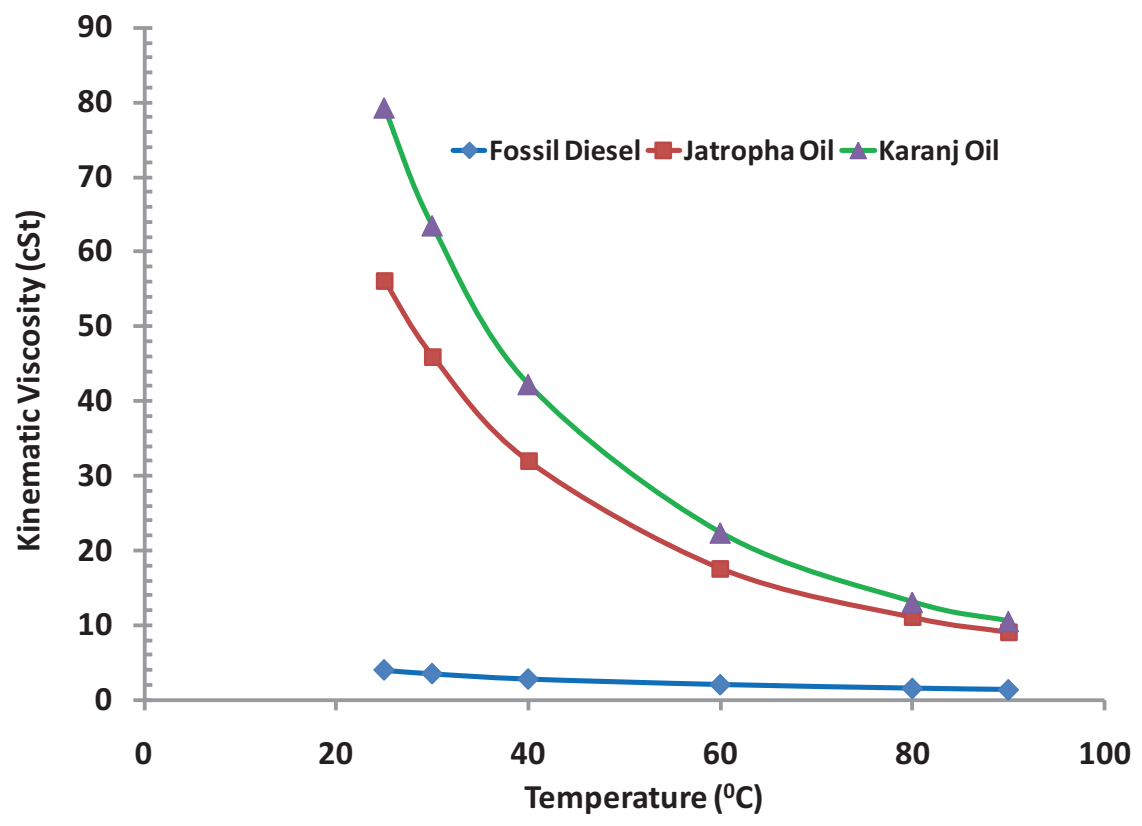

Fig. 3. Viscosity vs. temperature of jatropha, karanj and fossil diesel 


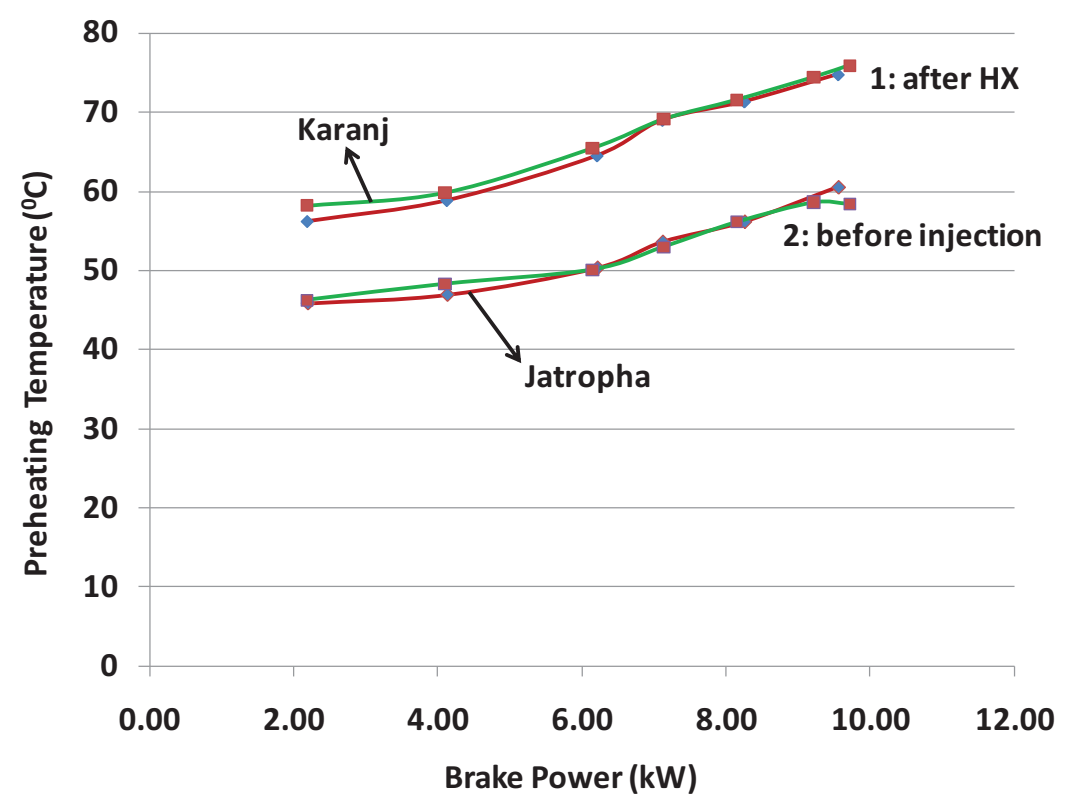

Fig. 4. Preheating temperatures of neat jatropha and karanj oils at different engine load conditions 


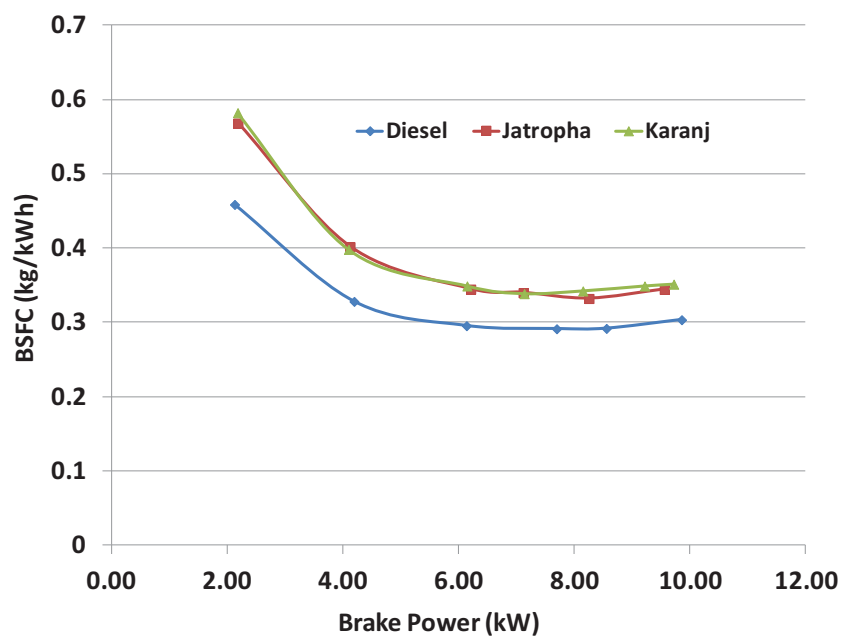

Fig. 5a - BSFC (kg/kWh) vs. load

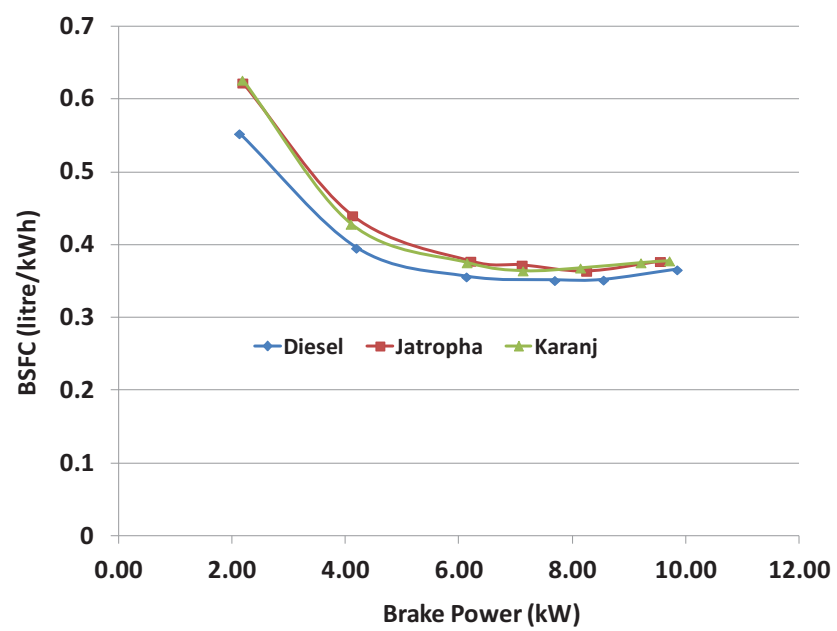

Fig. 5b - BSFC (litre/kWh) vs. load

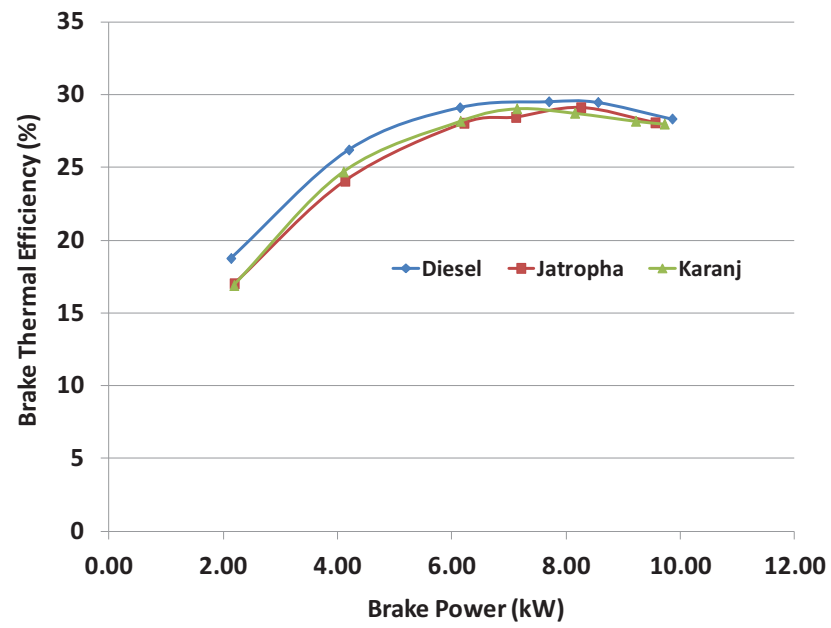

Fig. 5c - Brake thermal efficiency vs. load

Fig. 5. Brake specific fuel consumption and brake thermal efficiency vs. engine load 

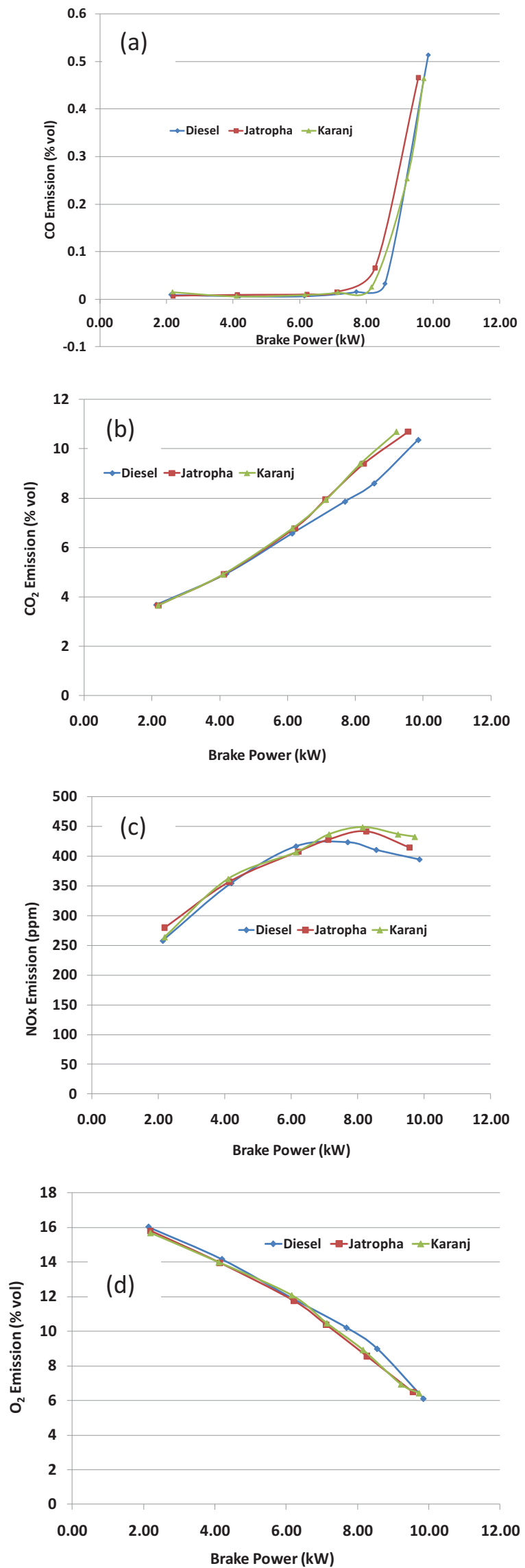

Fig. 6. Comparison of exhaust emissions at different engine load conditions: (a) $\mathrm{CO}$ emission, (b) $\mathrm{CO}_{2}$ emission, (c) $\mathrm{NO}_{\mathrm{x}}$ emission, and (d) $\mathrm{O}_{2}$ emission 


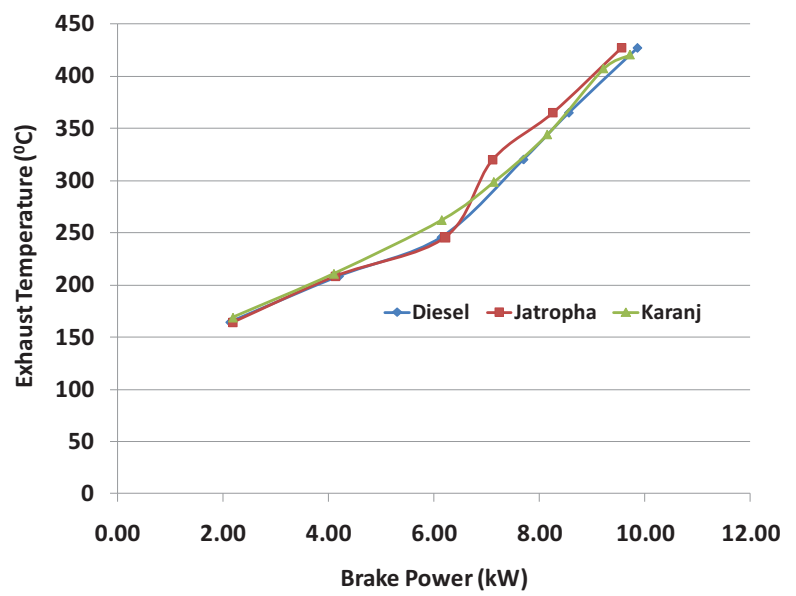

$7 \mathrm{a}-$ Exhaust temp vs. load

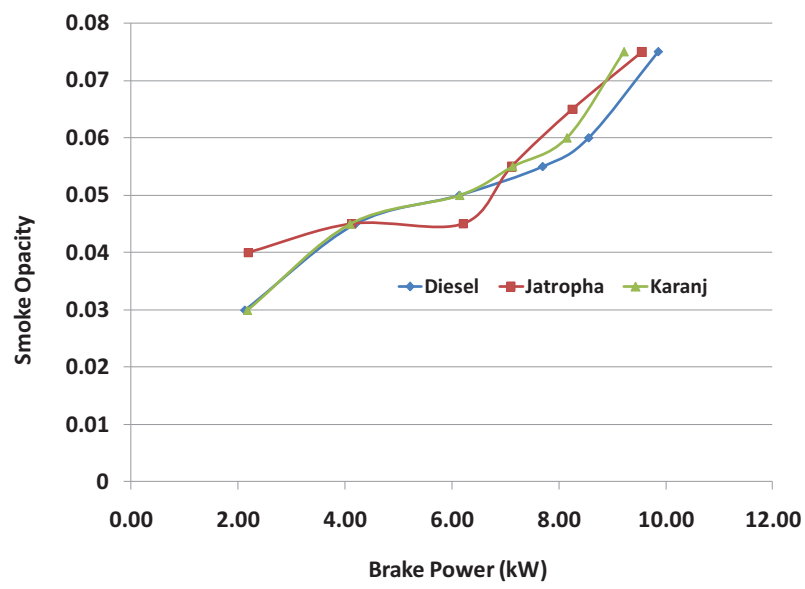

$7 \mathrm{~b}-$ Smoke opacity vs. load

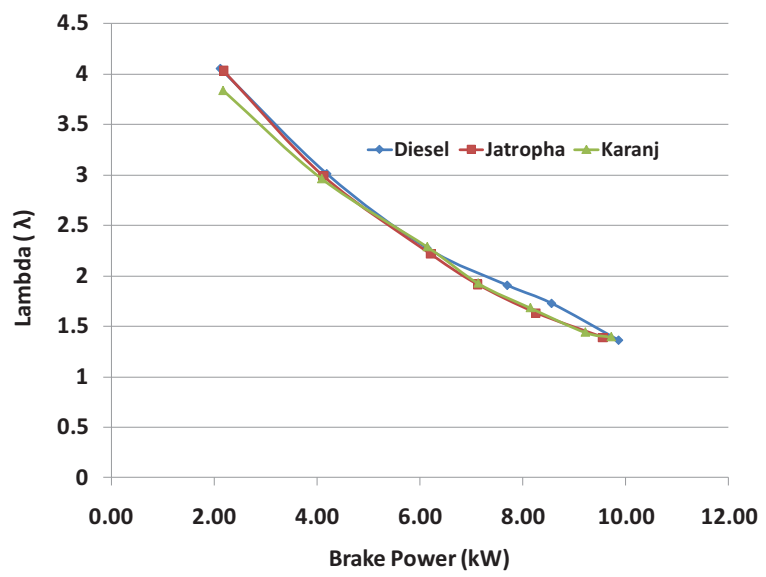

$7 \mathrm{c}$ - Lambda values vs. load

Fig. 7. Exhaust gas temperature, smoke opacity and lambda values vs. engine load 

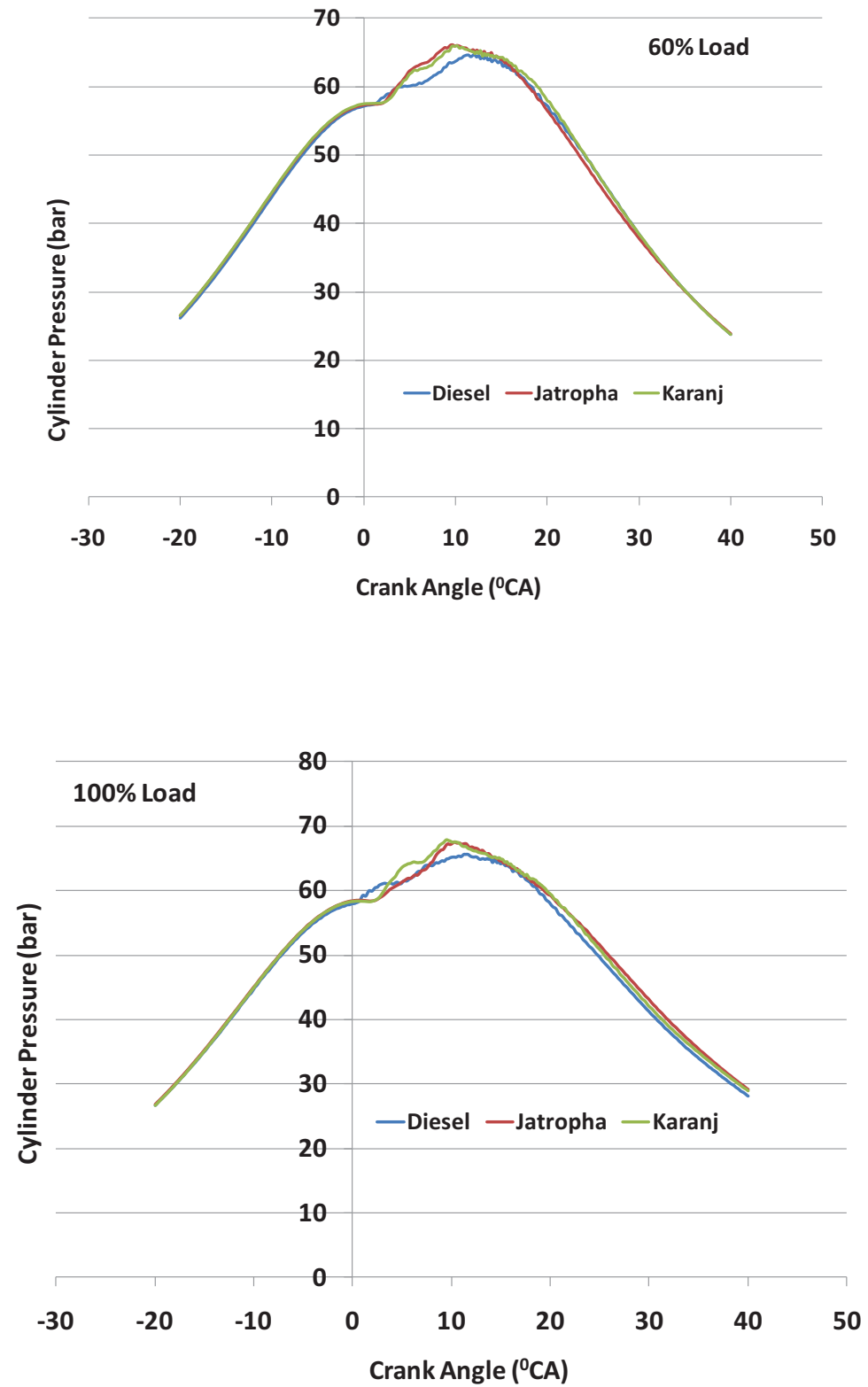

Fig. 8. Cylinder pressure vs. crank angle at different engine loads 

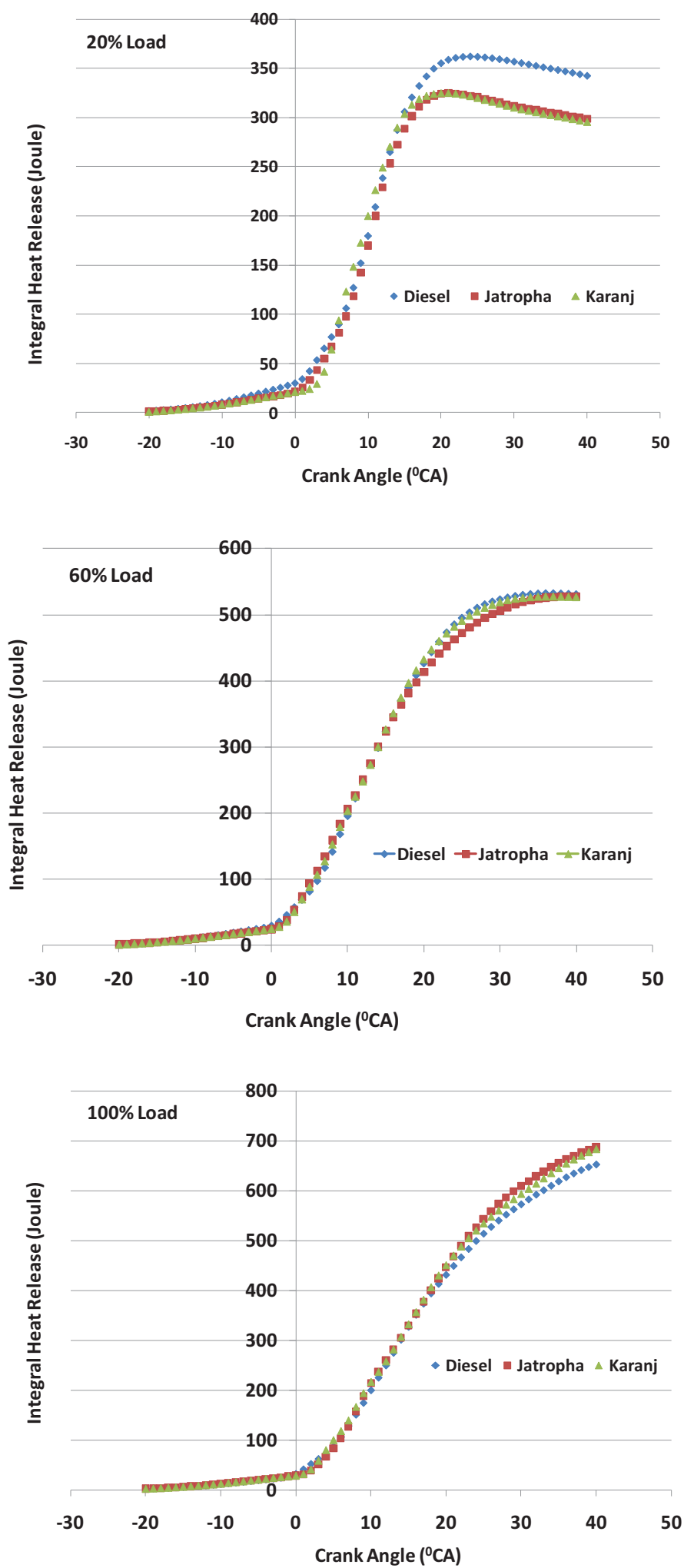

Fig. 9. Integral heat release vs. crank angle for different fuels and at different loads 


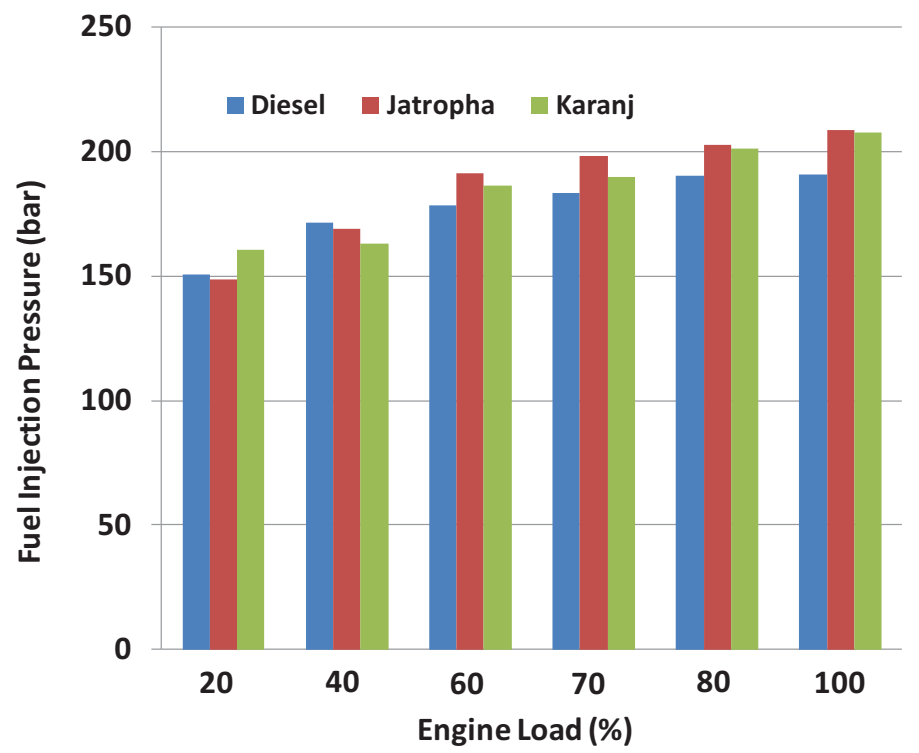

Fig. 10. Maximum fuel injection pressure vs. engine load 


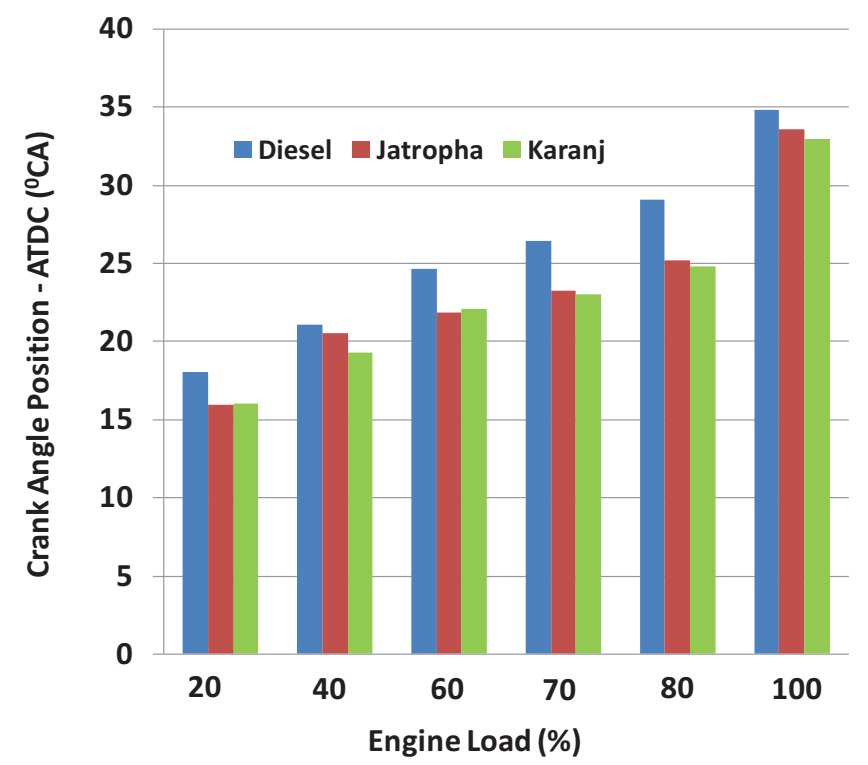

(a) $90 \%$ combustion

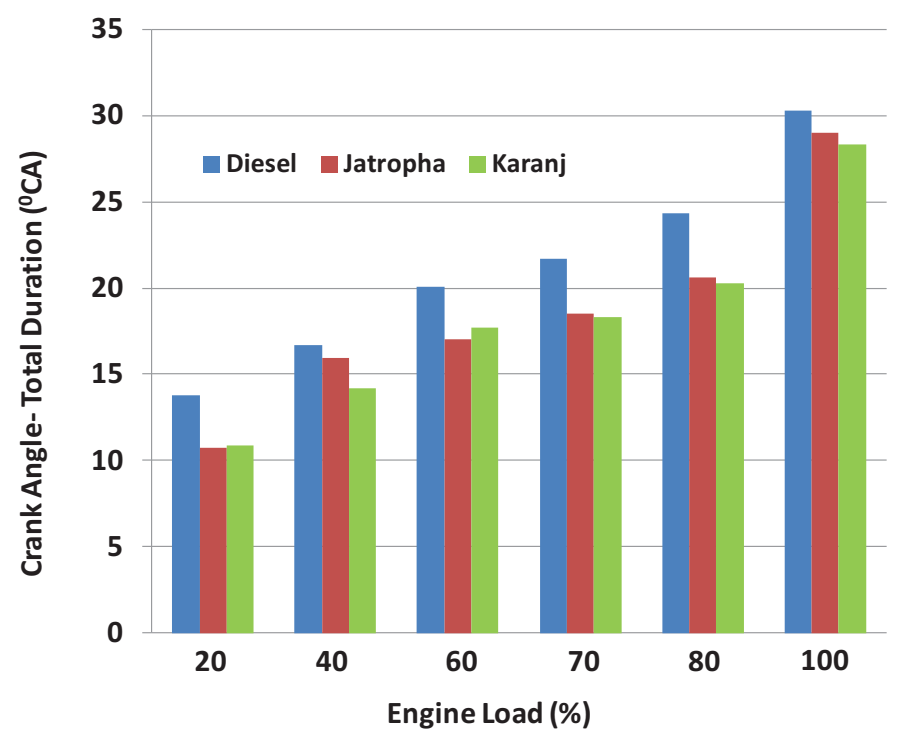

(b) Total combustion duration

Fig. 11. Combustion of fuels at various engine load conditions 
